\title{
ANALYTICAL STUDIES OF ASCORBIC ACID IN PHARMACEUTICALS \\ AND FRUIT JUICES USING DC POLAROGRAPHY
}

\author{
C. B. Masram ${ }^{1}$, R. M. Jugade ${ }^{2^{*}}$ \\ ${ }_{1}^{1}$ S.N. Mor Arts, Commerce and Smt. G. D. Saraf Science College, \\ Tumsar, Dist. Bhandara-441912. \\ 2Department of Chemistry, R.T.M. Nagpur University, Nagpur-440033. \\ Corresponding author E-mail: bhiny2m@yahoo.co.in
}

\begin{abstract}
DC polarographic method has been developed for analysis of ascorbic acid (vitamin C) in pharmaceutical formulations and fruit juices. Parameters like concentration of supporting electrolyte, maximum suppressor, $\mathrm{pH}$, mercury flow rate and drop time were optimized. Under optimum conditions, a well-defined sigmoid curve was observed with diffusion current proportional to the concentration of ascorbic acid. Analytical quality control was carried out with determination of relative mean deviation, standard deviation and regression studies. The method was found to be simple, rapid and reproducible. The optimized method was applied to various pharmaceutical formulations available in local market. The results obtained were found to be in agreement with the certified values.
\end{abstract}

Keywords: Ascorbic acid, Polarography, Pharmaceutical formulations

\section{INTRODUCTION}

Ascorbic acid is naturally occurring organic compound with antioxidant properties. It is commonly known as Vitamin C. Ascorbate usually acts as an antioxidant. Typically it reacts with oxidants such reactive oxygen species, such as the hydroxyl radical formed from hydrogen peroxide. Such radicals are damaging to animals and plants at the molecular level due to their possible interaction with nucleic acids, proteins, and lipids. Sometimes these radicals initiate chain reactions. Ascorbate can terminate these chain radical reactions by electron transfer. 
Common analytical techniques being used for the determination of ascorbic acid include spectrophotometry ${ }^{1,2}$, $\mathrm{HPLC}^{3}$, flow injection analysis $^{4,5}$, ion exchange ${ }^{6}$, turbidimetry ${ }^{7}$ and fluorimetry ${ }^{8}$. Polarographic and voltammetric techniques have been widely used in pharmaceutical analysis.9,10 This paper describes the polarographic investigations of ascorbic acid and its estimation in various marketed formulations and fruit juices.

\section{MATERIALS AND METHODS}

Apparatus: Polarographic studies have been carried out using Elico polarograph CL 25D attached with Elico XY-recorder. The electrode system consisted of dropping mercury electrode (DME) as working electrode and saturated calomel electrode (SCE) as a reference electrode. Saturated $\mathrm{KCl}$ salt bridge has been used for connecting the electrode systems. Height of mercury column was adjusted to get a flow rate of about 20 drops per minute. Nitrogen gas was used for deaeration and micropipette was used for addition of ascorbic acid solution. Mercury was purified by aeration method and then distilled under reduced pressure. The $\mathrm{pH}$ of the solutions were measured with the help of ELICO (Model LI-10) $\mathrm{pH}$ meter operating on $220 \mathrm{~V}$ stabilized AC mains. The electrode assembly was a glass-calomel supplied by the manufacturer. The $\mathrm{pH}$ meter was standardized every time before use with potassium hydrogen phthalate buffer $(\mathrm{pH} 4.0)$. Suitable temperature compensation adjustments were made. An electrically operated single pan balance, Mettler model H51AR, with least count of $0.01 \mathrm{mg}$ was used for weighing purposes.

Reagents and Solutions: All the chemicals used were of AR grade and the solutions were prepared in double distilled water. Stock solution ascorbic acid was prepared by dissolving appropriate weight and desired dilutions were made as per the requirements. Stock solutions of 
maximum suppressor and various buffers were prepared by dissolving required amounts in double distilled water.

General procedure: In each determination, $25 \mathrm{~mL}$ of biphthalate buffer with $0.25 \%$ oxalic acid solution was taken and $1 \mathrm{ml}$ maximum suppressor was added. $\mathrm{pH}$ was adjusted using dilute $\mathrm{NaOH}$ and $\mathrm{HCl}$ solutions. Desired volume of ascorbic acid solution was added and deaerated with nitrogen gas for 15 minutes. Polarograms were recorded using optimized conditions.

\section{RESULTS AND DISCUSSION}

Polarographic studies were carried out using different buffer systems as supporting electrolytes. It was found that the value of half wave potential as well as diffusion current changes with change in supporting electrolyte (Table 1). Among these buffer systems, the biphthalate buffer was found to give a well-defined polarographic wave with half wave potential of $0.150 \mathrm{~V}$.

Table 1: Polarographic Behaviour of Ascorbic Acid in different media

\begin{tabular}{|c|c|c|c|}
\hline Supporting Electrolyte & $\begin{array}{c}\mathrm{E}_{1 / 2} \text { against } \\
\text { SCE } \\
\text { (V) }\end{array}$ & $\begin{array}{c}\text { Diffusion } \\
\text { Coefficient } \\
\left(\mathrm{cm}^{2} \sec ^{-1}\right)\end{array}$ & $\begin{array}{c}\text { Diffusion } \\
\text { current } \\
\text { constant } \\
\left(\mathrm{id}_{\mathrm{d}} / \mathrm{cm}^{2 / 3} \mathrm{t}^{1 / 6}\right)\end{array}$ \\
\hline Biphthalate buffer & +0.105 & $5.7 \times 10^{-6}$ & 3.00 \\
\hline $\begin{array}{l}\text { Phosphate buffer with } 1.5 \% \\
\text { metaphosphoric acid }\end{array}$ & +0.217 & $6.2 \times 10^{-6}$ & 3.04 \\
\hline $\begin{array}{l}\text { Biphthalate buffer with } 0.25 \\
\text { oxalic acid and } 50 \% \text { ethanol }\end{array}$ & +0.060 & $3.6 \times 10^{-6}$ & 2.34 \\
\hline $\begin{array}{l}\text { Biphthalate buffer with } 3 \% \\
\mathrm{HPO}_{3}\end{array}$ & +0.240 & $5.3 \times 10^{-6}$ & 2.88 \\
\hline
\end{tabular}

The $\mathrm{pH}$ of the buffer system was varied from 2.25 to 9.5. It was observed that the half wave potential goes on decreasing with increase in $\mathrm{pH}$ resulting in cathodic shift with increase in $\mathrm{pH}$. No polarographic wave 
was observed above $\mathrm{pH}$ 4.5. A well-defined polarographic wave with half wave potential $0.105 \mathrm{~V}$ was observed at $\mathrm{pH} 4.1$ which was selected for further studies.

Effect of maxima suppressors like gelatin, triton-X 100, bromocresol green, methyl thymol blue, methyl red, etc was studied. It was observed that the current wave is highly reproducible when $0.008 \%$ gelatin solution is used as a maximum suppressor.

Instrumental conditions like mercury flow rate, scan rate etc were adjusted to get a sharp single wave with high reproducibility. Under optimum conditions of $\mathrm{pH}$, maxima suppressor, mercury flow rate and scan rate, the diffusion current was found to be directly proportional to the concentration of ascorbic acid. The regression coefficient was found to be 0.9996 with equation of regression line $\boldsymbol{y}_{(\mu \mathrm{A})}=0.0748 \boldsymbol{x}_{(\mathrm{mg} / \mathrm{L})}-0$ .0259. The $3 \sigma$ detection limit was found to be $2 \mathrm{mg} \mathrm{L}^{-1}$. Typical polarograms obtained under optimum conditions have been shown in Figure 1.

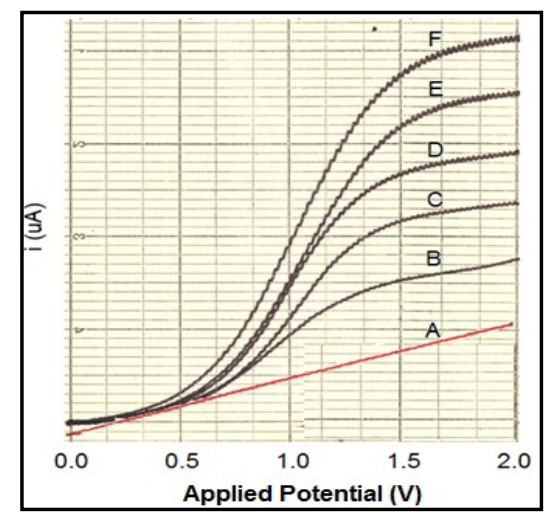

Fig. 1: DC polarograms of ascorbic acid at different concentrations (A) Blank (B) 26 $\mathrm{mgL}^{-1}$, (C) $35 \mathrm{mg} \mathrm{L}^{-1}$, (D) $44 \mathrm{mg} \mathrm{L}^{-1}$ and (E) $53 \mathrm{mg} \mathrm{L}^{-1}$ ascorbic acid

\section{APPLICATION}

The developed method was applied to the determination of ascorbic acid in various pharmaceutical formulations in the local market and three fruit samples. The quoted and observed values for the 
pharmaceuticals have been shown in Table 2 while those for the fruit samples have been presented in Table 3. The observed values agree with the reported values in most of the samples. Also, presence of other components does not interfere with estimation of ascorbic acid.

Table 2: Estimation of Ascorbic Acid in pharmaceutical formulations

\begin{tabular}{|l|c|c|}
\hline \multirow{2}{*}{ Medicinal Sample } & \multicolumn{2}{|c|}{ Amount of Ascorbic Acid (mg) } \\
\cline { 2 - 3 } & Reported value & Observed value* \\
\hline Polybion Tablet & 150 & $146.3 \pm 3.2$ \\
\hline Basiton Forte Tablet & 150 & $140.1 \pm 4.8$ \\
\hline Beplex Forte Tablet & 150 & $128.6 \pm 3.9$ \\
\hline
\end{tabular}

*(Avg $\pm \mathrm{SD})$ of 3 values

Table 3: Estimation of Ascorbic Acid in Fruit Juices

\begin{tabular}{|l|c|}
\hline \multicolumn{1}{|c|}{ Fruit } & Amount of Ascorbic Acid (mg L'-1 \\
\hline Lemon & $372 \pm 8$ \\
\hline Orange & $458 \pm 6$ \\
\hline Grapes & $390 \pm 11$ \\
\hline
\end{tabular}

*(Avg $\pm \mathrm{SD})$ of 3 observations

\section{CONCLUSION}

The developed method was rapid, simple, reproducible and accurate. It could be applied to various pharmaceutical formulations and fruit samples. The Standard deviation, relative mean deviation and coefficient of variation are found to be $0.97,3.2 \%$ and $3.5 \%$ respectively. An important advantage of the method is that it is possible to determine concentration of ascorbic in the presence of other commonly occurring ingredients.

\section{ACKNOWLEDGEMENT}

The authors are thankful to UGC, New Delhi for start-up grant. 


\section{REFERENCES}

Pachla LA, Reynolds DL, Kissinger PC, (1985) Analytical methods for determining ascorbic acid in biological samples, food products, and pharmaceuticals, J Assoc Off Anal Chem, 68: 1-12.

Tabata M, Morita H, (1997) Spectrophotometric determination of a nanomolar amount of ascorbic acid using its catalytic effect on copper(II) porphyrin formation, Talanta 44:151-157.

Nayyssonen K, Parviainen S, Parviainen MT, Heinonenk K, Mononen I, (1988) Quantitative estimation of dehydroascorbic acid and ascorbic acid by high-performance liquid chromatography: application to human milk, J Liq Chromatogr, 11: 1717-1728.

Yebra-Biurrun MC, Cespon-Romero RM, Barrera PB, (1997) Indirect flow-injection determination of ascorbic acid by flame atomic absorption spectrometry, Microchim Acta, 126, 53-58.

Leon LE, Catapano J, (1993) Indirect Flow-Injection Analysis of Ascorbic Acid by Photochemical Reduction of Methylene Blue, Anal Lett, 26, 1741-1750.

Teshima N, Nabuta T, Sakai T, (2001) Simultaneous flow injection determination of ascorbic acid and cysteine using double flow cell, Anal Chim Acta, 438, 21-29.

Farajzadeh MA, Nagizadeh S, (2002) A new simple and accurate turbidimetric method for determination of ascorbic acid in pharmaceuticals and fruits, J Chinese Chem Soc, 49, 949-954.

Kall MA, Andersen C, (1999) Improved method for simultaneous determination of ascorbic acid and dehydroascorbic acid, isoascorbic acid and dehydroisoascorbic acid in food and biological samples, J Chromatogr B Biomed Sci Appl, 25,101-11.

Jeyaseelan C, Jugade R, Joshi AP, (2006) Differential Pulse Polarographic Studies of Risperidone in Pharmaceutical Formulations, Croatica Chimica Acta, 79, 541-544.

Jugade R, Jeyaseelan C, Joshi AP, (2011) Trace determination of azathioprene by differential pulse polarography, Int $\mathrm{J}$ Pharm Sci Rev and Res, 11, 38-41. 